Article

\title{
Tree Growth and Wood Quality in Pure Vs. Mixed-Species Stands of European Beech and Calabrian Pine in Mediterranean Mountain Forests
}

\author{
Diego Russo ${ }^{1}$, Pasquale A. Marziliano ${ }^{1, *(1)}$, Giorgio Macrì ${ }^{1}$, Giuseppe Zimbalatti ${ }^{1}$, \\ Roberto Tognetti ${ }^{2,3}$ (D) and Fabio Lombardi ${ }^{1}$ (D) \\ 1 Department of AGRARIA, Mediterranean University of Reggio Calabria, 89122 Reggio Calabria, Italy; \\ diego.russo@unirc.it (D.R.); giorgio.macri@unirc.it (G.M.); gzimbalatti@unirc.it (G.Z.); \\ fabio.lombardi@unirc.it (F.L.) \\ 2 Department of Agricultural, Environmental and Food Sciences, University of Molise, 86100 Campobasso, \\ Italy; tognetti@unimol.it \\ 3 The EFI Project Centre on Mountain Forests (MOUNTFOR), Edmund Mach Foundation, Via Edmund Mach, \\ 38010 San Michele all'Adige, Italy \\ * Correspondence: pasquale.marziliano@unirc.it; Tel.: +3909651694256
}

Received: 2 October 2019; Accepted: 16 December 2019; Published: 18 December 2019

\begin{abstract}
Mixed-species forests may deliver more forest functions and services than monocultures, as being considered more resistant to disturbances than pure stands. However, information on wood quality in mixed-species vs. corresponding pure forests is poor. In this study, nine plots grouped into three triplets of pure and mixed-species stands of European beech and Calabrian pine (three dominated by European beech, three dominated by Calabrian pine, and three mixed-species plots) were analysed. We evaluated tree growth and wood quality through dendrochronological approaches and non-destructive technologies (acoustic detection), respectively, hypothesizing that the mixture might improve the fitness of each species and its wood quality. A linear mixed model was applied to test the effects of exogenous influences on the basal area index (BAI) and the dynamic modulus of elasticity (MOEd). The recruitment period (Rp) was studied to verify whether wood quality was independent from stem radial growth patterns. Results showed that the mixture effect influenced both wood quality and BAI. In the mixed-species plots, for each species, MOEd values were significantly higher than in the corresponding pure stands. The mixture effect aligned MOEd values, making wood quality uniform across the different diameter classes. In the mixed-species plots, a significant positive relationship between MOEd and Rp, but also significantly higher BAI values than in the pure plots, were found for European beech, but not for Calabrian pine. The results suggest the promotion of mixing of European beech and Calabrian pine in this harsh environment to potentially improve both tree growth and wood quality.
\end{abstract}

Keywords: TreeSonic; MOEd; forest productivity; dendrochronology; recruitment period; Aspromonte National Park

\section{Introduction}

Mixed-species forests may deliver forest functions and services more effectively than monocultures [1,2], particularly in threatened mountain environments [3] and in man-made mixed-species forests. Therefore, their spread is an important option to adapt European mountain forests and forestry to future disturbances and extreme events [4]. Mixed-species forests may show less temporal variation in growth and more stable productivity in comparison with pure stands, due to reduced tree species competition for resources [5-13]. Nevertheless, contradictory mixed-species effects 
on tree growth have been found under conditions favouring drought stress or in dry years [14-16]. Gebauer et al. [17] observed that stand-level canopy transpiration was not higher in mixed broad-leaved forests than in pure European beech stands and that the spatial complementarity in root water uptake of mixed-species stands could be masked by edaphic conditions preventing the vertical stratification of species-specific root systems. An increase in the frequency and severity of drought events, as predicted for the coming decades $[18,19]$, will have dramatic implications for the resilience of Mediterranean mountain ecosystems, particularly in the case of forest stands with a simplified vertical structure [20]. Indeed, species-specific functional traits and allometric relations can be more important for stand water use than tree species diversity per se. Therefore, more insight into species mixing, structural diversity and forest dynamics is essential for modeling risk assessment and forest functions aimed at fostering alternative silvicultural practices in harsh environments.

Although mixed-species stands can be more productive in comparison with monocultures [21-24] up to $30 \%$ [25], site conditions, stand age, and tree species interactions affect these responses [26,27]. Focusing on the causes of differences in tree growth and stand productivity between mixed-species and pure forests, most research addressed environmental settings and relationships with climatic conditions, species composition, mixture type, and stand age [28-36]. Indeed, few studies exist on the quality and value of wood produced in mixed-species vs. corresponding pure stands [37]. Information on how wood quality can be affected in relation to tree species composition is essential for decision making in adaptive forestry, especially where forest planning and thinning activities favour the occurrence of mixed-species stands [27].

Liu et al. [38] showed that spacing and thinning experiments in pure stands highlighted the strong effect of the surrounding spatial stand structure on tree growth and morphology and, ultimately, wood structure and timber quality. Chomel et al. [39] demonstrated that, in mixed-species plantations, mixing hybrid poplar and white spruce might increase the wood production of poplar in comparison with monocultures of either poplar or white spruce. Battipaglia et al. [40] showed a considerable increase in cumulative basal area and in intrinsic water use efficiency in mixed-species stands of pedunculate oak and Italian alder, largely resulting from an increase in N fixation, which levelled off, when natural mortality or management practices decreased the competitive ability of Italian alder. In addition to stand productivity and water use efficiency, species mixtures with structural stratification may also enhance individual-tree growth rates and stem quality of species in the upper canopies, minimizing the proportion of taller species that reach the highest production [6,41].

Forest management practices oriented to obtain mixed-species stands potentially determine variation in the physical and mechanical properties of the harvested wood, both at stand and tree level [42]. Nevertheless, although mixed-species forestry is gaining popularity in Europe [10,43], a greater understanding of the differences in wood quality between mixed-species vs. corresponding pure stands is needed. In the last decades, the evaluation of wood quality has been preferentially based on non-destructive technologies (NDTs) [44]. More specifically, stress wave-based non-destructive acoustic techniques resulted in very useful methods for predicting the mechanical properties of woody materials [45]. Nowadays, acoustic sensing technology allows for the estimation of wood quality and intrinsic woody properties for standing trees, stems and logs. Among the parameters measurable by acoustic methods, the most important is the dynamic modulus of elasticity (MOEd), being related to wood anatomy and tree physiology. This parameter can be used for the evaluation of wood quality, providing information on the stiffness of material $[46,47]$.

In this study, the wood quality term refers to the use of wood in the field of construction. The wood properties that determine the structural requirements are defined by indicators, such as strength grades, that depend on knottiness, stiffness and density of the wood [48]. These parameters are commonly used worldwide to define strength grades [49]. With reference to stiffness, the dynamic modulus of elasticity (MOEd) is considered a good predictor, so as to be used as a proxy variable for assessing the wood quality and, in particular, its stiffness [50]. As a matter of fact, profound implications for 
wood properties and utilization derive from the growth and ecophysiological responses of trees to environmental conditions.

We focused on two important tree species, European beech (Fagus sylvatica L.) and Calabrian pine (Pinus nigra Arnold subsp. calabrica), widespread in mountainous forest ecosystems of Southern Italy; European beech is a late-successional broadleaved tree species, here occurring in its southernmost ecological limit, whereas Calabrian pine is an early-successional conifer, providing timber of high quality. In the Calabrian Apennines, these species occur in both pure and corresponding mixed-species stands, which may help test the effects of mixture on tree growth and wood quality in a drought-prone environment. Our study comprises nine plots grouped into three triplets of pure and mixed-species stands of European beech and Calabrian pine (three dominated by European beech, BP, three dominated by Calabrian pine, $\mathrm{PP}$, and three mixed-species plots, MBP), in the Aspromonte National Park. The three stands grow in the same environmental conditions and show similar structural traits. We hypothesized that the mixture effect may improve the physiological fitness of each species and, thus, the wood quality. The specific objectives of the study were to: (Q1) evaluate the wood quality (MOEd), (Q2) analyse tree growth patterns through the basal area index (BAI), and (Q3) highlight potential relationships between wood quality and tree growth, in mixture vs. monocultures. In particular, we tested whether (i) the mean wood quality in mixed-species and corresponding pure stands are equal, (ii) the mean BAI in pure and mixed-species stands are equal, and if (iii) the wood quality and tree growth patterns are independent.

\section{Materials and Methods}

\subsection{Study Area}

The study area is located in the Aspromonte National Park, Calabria (Southern Italy), near the village of Bagaladi (RC). The climate is temperate, with an annual mean temperature of around $8{ }^{\circ} \mathrm{C}$ and minimum and maximum monthly means of $0.5^{\circ} \mathrm{C}$ (coldest month) and $16^{\circ} \mathrm{C}$ (warmest month), respectively. Annual precipitation is $1611 \mathrm{~mm}$ unevenly distributed over the year (Meteorological station of Gambarie d'Aspromonte-1187 m above sea level (a.s.l.).

The study is based on nine plots (each with an extension of $5000 \mathrm{~m}^{2}$ and square shape), grouped into three triplets of pure and mixed-species stands of European beech and Calabrian pine, using a randomized block design. Plots within each block were randomly assigned to the units. Each triplet, extended over 1.5 ha, contains two monospecific plots, dominated by European beech (BP) or Calabrian pine (PP), and one mixed-species European beech-Calabrian pine stand (MBP). The pure stands were selected if the target species represented $\sim 90 \%$ of the stand basal area. The mixed-species stand was defined as the stand in which the two species together represented at least $\sim 80 \%$ of the total stand basal area and the sum of the basal area of other species was lower than that of each of the two studied species. In order to quantify the mixing effects, the pure stands were used as reference for the mixed-species stand.

Plots are located in similar environmental conditions in terms of environmental settings (topography, slope, substrate) and climatic conditions. Soils developed from igneous and metamorphic rocks and are classified as Umbrisols, Cambisols and Leptosols [51], with an udic soil regime moisture. Further details on the main environmental conditions characterizing the study site are reported in Table 1.

These forest stands are of natural origin, with a dominant age ranging from 70 to 120 years old. They evolved naturally in the last 70 years. However, these forests (approximately until the Second World War) were cut following a management approach based on the "selection cutting" criteria, in which few trees were cut approximately every 20 years in the same forest section [52]. This type of management has preserved the typical forest landscape by maintaining a continuous forest cover, determining a stand structure consisting of clusters of trees in different age classes. These clusters are 
the result of the natural regeneration occurring in the gaps opened by the selection cutting previously applied [52].

Table 1. The main geographical features of the investigated triplets located nearby the village of Bagaladi, RC (Aspromonte National Park).

\begin{tabular}{cccc}
\hline & Triplet 1 & Triplet 2 & Triplet 3 \\
\hline Latitude $(\mathrm{N})$ & $38^{\circ} 06^{\prime} 50.53^{\prime \prime}$ & $38^{\circ} 05^{\prime} 54.59^{\prime \prime}$ & $38^{\circ} 06^{\prime} 15.69^{\prime \prime}$ \\
Longitude $(\mathrm{E})$ & $15^{\circ} 51^{\prime} 53.25^{\prime \prime}$ & $15^{\circ} 50^{\prime} 37.72^{\prime \prime}$ & $15^{\circ} 51^{\prime} 23.37^{\prime \prime}$ \\
Exposure $\left(^{\circ}\right)$ & 59 & 59 & 59 \\
Altitude $(\mathrm{m}$ a.s.l.) & 1521 & 1511 & 1497 \\
Slope $\left(^{\circ}\right)$ & 28 & 30 & 34 \\
\hline
\end{tabular}

\subsection{Tree Sampling and BAI Analyses}

In 2017, in order to derive the dendrometric variables at the stand level, the nine plots were fully inventoried. The diameters at breast height $(\mathrm{DBH})$ and the total heights $(\mathrm{Ht})$ of all trees were measured. Tree volume was calculated using the equations derived for the prediction of the aboveground tree volume [53]. Canopy dominant/co-dominant trees were targeted for sampling (coring and measuring MOEd) and were selected through a stratified random sampling, in relation to the frequency of the diameter classes at the plot level. In detail, in each monospecific stand (BP and PP), 30 dominant trees per species were cored, while 60 dominant trees were cored (30 for European beech and 30 for Calabrian pine) in MBP. For each selected tree, two increment cores were collected at breast height and at an angle of $120^{\circ}$ to each other. Particular care was taken to select trees with canopies well separated from each other. Moreover, to avoid the effect of wood alteration and exogenous disturbances on tree ring growth, only trees without abrasion scars or other visible evidence of injury were selected. Cores were then mounted on channeled wood, seasoned in a fresh-air dry store and sanded a few weeks later. Ring widths were measured with a resolution of $0.01 \mathrm{~mm}$ using the LINTAB measurement equipment (Frank Rinn, Heidelberg, Germany) fitted with a Leica MS5 stereoscope (Leica Microsystems, Wetzlar, Germany). Tree ring widths were then statistically cross-dated and verified with the software TSAP software package (version 4.81c) and COFECHA (version 6.06) [54]. Once all measurement series were validated, tree-ring chronologies were developed for each species. Subsequently, tree ring widths were converted into tree basal area increment (BAI), according to the following standard formula:

$$
B A I=\pi\left(r_{n}^{2}-r_{(n-1)}^{2}\right)
$$

where $r$ is the radius of the stem at breast height and $\mathrm{n}$ is the year of tree-ring formation. In order to examine the mean growth trend for the sampled trees, BAI for each year was averaged over all the individuals for removing the variation in radial growth attributable to the increasing tree circumference.

The latest fully built tree ring valid for our analysis was related to 2016. We considered only the tree-ring chronologies starting from 1900, because few trees had rings formed before the year 1900.

\subsection{Wood Quality}

In order to evaluate the wood quality, acoustic wave tests were conducted at breast height on the same 120 trees from which the woody cores were collected. In order to reduce the effect of air humidity [55], the tests were carried out in the summer of 2017, from June to July.

TreeSonic (FAKOPP TreeSonic ${ }^{\mathrm{TM}}$ Fakopp Enterprise, Agfalva, Hungary) [44,56] was used for measuring the acoustic velocity. It is characterized by a hand-held hammer and two probes, a transmitting accelerometer and a receiving accelerometer. The system consists in the insertion of two sensor probes (a transmitting probe and a receiving one) into the sapwood, applying acoustic energy into the tree stem through hammer impact. The probes were aligned within a vertical plane on the same face. In our study, a 1.00-m testing span was roughly centered at breast height. The lowest probe 
was placed about $60-70 \mathrm{~cm}$ above the forest floor. Three measurements were realized for each selected tree and the average of the three recordings was used as final transit time. In order to measure the acoustic velocity wave, the start and stop sensors were driven at a $45^{\circ}$ angle through the bark into the wood of the standing tree [57]. Acoustic velocity was determined on the upstream side of the tree (according to standard procedure), the same side where the stem diameter was measured. The acoustic velocity (CT) was then calculated from the span between the two sensor probes and the time-of-flight (TOF) data, using the following formula:

$$
\mathrm{CT}=\mathrm{S} / \mathrm{TOF}
$$

where CT $=$ tree acoustic velocity $(\mathrm{m} / \mathrm{s}), \mathrm{S}=$ distance between the two probes (sensors) (m), TOF = time-of-flight (s).

The wood density of each measured tree was also determined on the woody cores. The fresh weight and volume of the tree cores were measured in the laboratory. Woody samples were weighed to the nearest $0.01 \mathrm{~g}$ with an electronic scale. After ring width measurements, the woody cores were dried in oven at $105^{\circ} \mathrm{C}$, to constant weight. Density $\left(\mathrm{kg} \mathrm{m}^{-3}\right)$ was calculated by dividing the dry weight by the fresh volume.

Afterwards, it was possible to calculate the modulus of elasticity (MOE), according to the following equation:

$$
\mathrm{MOEd}=\mathrm{WD}_{\mathrm{i}} \times \mathrm{CT}^{2}
$$

where $\mathrm{WD}_{\mathrm{i}}=$ tree wood density $\mathrm{i}\left(\mathrm{kg} \mathrm{m}^{-3}\right)$ and $\mathrm{CT}=$ velocity $\left(\mathrm{km} \mathrm{s}^{-1}\right)$.

When MOE is estimated using the above formula, it is termed dynamic modulus of elasticity (MOEd) [58], as the stress wave propagation in wood is a dynamic process, internally related to the physical and mechanical properties of wood [59].

\subsection{Relationship between Wood Quality and Tree Growth}

In standing trees, the stress wave propagation is affected by tree stem diameter, wood travel distance and internal wood conditions [60]. Furthermore, the mean tree values of timber grade-determining properties (elastic modulus, bending strength, and wood density) are related to the acoustic velocity and tree slenderness. Signals are transferred through the whole stem, depending on stem diameter: when smaller is the diameter, then the signal is more transferred inside the stem [61]. In this study, we used the tree final growth time to evaluate the relationship between wood quality and tree growth, in order to verify if the wood quality was independent from tree growth. In detail, the final growth time is given by the number of radial rings included in the outermost $2.5 \mathrm{~cm}$ of the sampled trees. This parameter is called "recruitment period" (RP), which indicates the number of years needed to pass from a diameter class $x_{i}$ to the largest class $x_{i}+5$, assuming classes of $5 \mathrm{~cm}$ [62]. Therefore, for each sampled tree, we counted the number of rings contained in the last $2.5 \mathrm{~cm}$.

\subsection{Statistical Analysis}

The data collected were characterized by a nested structure and they were not independent from each other: in detail, an inter-correlation among samples occurred, since they were referred to the same triplets, and the single tree ring chronologies belonged to one single tree. Therefore, an analysis based on a linear mixed model was used, including both fixed and random effects. We then set up the model functions to test the effect of mixing on tree ring width (expressed as BAI) and on the MOEd. The linear mixed models incorporated the triplet identifier as a random effect, thus considering both the mixing effect (expressed as percentage of basal area of the examined species of beech or pine, compared to the total area) and the nested structure of the data. The initial model included the following independent variables: basal area, stem $\mathrm{DBH}$, tree height, tree age. A stepwise procedure (in each step, a variable was considered for addition to or subtraction from the set of explanatory variables based on $F$-tests) eliminated all variables, except for the basal area, the only variable that had a significant effect on 
the dependent variable. Therefore, the below model, based only on mixing effect and the nested design of data, was applied to evaluate if significant differences on BAI between mixed-species and corresponding pure stands occurred:

$$
B A I_{i j}=\beta_{0}+\beta_{1} \times M i x_{i j}+u_{j}+\varepsilon_{i j}
$$

where $B A I_{i j}$ is the mean of the basal area increment per tree $i$ on triplet $j, \beta_{0}$ is the intercept, Mix $x_{i j}$ is the fixed effect describing the quantification of the mixing effect (expressed as \% basal area) on tree BAI for tree $i$ on triplet $j, u_{j}$ is the random effect for triplet $j$ and $\varepsilon_{i j}$ is the error term. Moreover, the following model was used to analyse the effect of both mixture and tree ring width (expressed as recruitment period) on wood quality (MOEd values), incorporating the triplet identifier as a random effect:

$$
M O E d_{i j}=\beta_{2}+\beta_{3} \times M i x_{i j}+\beta_{4} \times R P_{i j}+u_{j}+\varepsilon_{i j}
$$

where $M O E d_{i j}$ is the wood quality of tree $i$ on triplet $j, R P_{i j}$ is the recruitment period of tree $i$ on triplet $\mathrm{j}$, examined as the main effect. For the linear mixed-effect model analysis, the nlme package for the R programming language [63] was used. In addition to the linear mixed-effect models, the Mann-Whitney Test for independent-sample ( $U$-Test) was also used to compare the average MOEd values and the average BAI values between mixed-species and pure stands. More specifically, the $U$-test is a non-parametric test and requires no assumptions.

\section{Results}

Table 2 shows the main structural and dendrometric characteristics of the studied stands, while in Table 3, the age, the wood density, the acoustic velocity and the MOEd for the sampled trees are reported. Forest structure did not differ markedly among the studied stands. Analysis of variance (ANOVA) showed no significant differences among plots in stand density $\left(F_{3 / 6}=1.020 ; p=0.447\right)$, tree $\mathrm{DBH}\left(F_{3 / 6}=0.329 ; p=0.805\right)$, basal area $\left(F_{3 / 6}=2.104 ; p=0.201\right)$ and stand volume $\left(F_{3 / 6}=2.208\right.$; $p=0.188)$. The number of trees per hectare varied from 743 in the pure European beech plots to 873 in the mixed-species plots. The tree volume ranged between $773 \mathrm{~m}^{3} \mathrm{ha}^{-1}$ in the pure European beech plots and $876 \mathrm{~m}^{3} \mathrm{ha}^{-1}$ in the mixed-species plots.

Table 2. Structural traits obtained for the investigated triplets. Mean values and the related standard deviation (in bracket) are reported.

\begin{tabular}{cccccc}
\hline & $\begin{array}{c}\text { Stand Density } \\
(\mathbf{N} . \text { Trees ha-1 }\end{array}$ & $\begin{array}{c}\text { Tree } \mathbf{~ D B H} \\
\mathbf{( c m})\end{array}$ & $\begin{array}{c}\text { Tree Height } \\
\mathbf{( m )}\end{array}$ & $\begin{array}{c}\text { Basal Area } \\
\mathbf{( m}^{\mathbf{2}} \mathbf{h}^{-\mathbf{1}} \mathbf{)}\end{array}$ & $\begin{array}{c}\text { Stand Volume } \\
\mathbf{( m}^{\mathbf{3}} \mathbf{h a}^{-\mathbf{1}} \mathbf{)}\end{array}$ \\
\hline Beech pure & $743(155.7)$ & $33.2(2.8)$ & $24.2(2.2)$ & $64.3(4.6)$ & $772.7(41.5)$ \\
Pine pure & $754(96.3)$ & $35.6(4.4)$ & $23.1(0.8)$ & $75.1(10.4)$ & $857.6(160.9)$ \\
MBP-B & $470(75.9)$ & $28.3(2.3)$ & $18.8(1.3)$ & $29.6(6.3)$ & $277.0(31.1)$ \\
MBP-P & $403(74.1)$ & $40.3(9.6)$ & $23.6(5.1)$ & $51.4(14.1)$ & $599.1(90.7)$ \\
\hline
\end{tabular}

Table 3. Tree age, wood density, acoustic velocity, and MOEd values obtained for the two studied species in the pure and mixed-species stands (SD: standard deviation; MOEd: dynamic modulus of elasticity).

\begin{tabular}{ccccccccc}
\hline \multirow{2}{*}{ Stands } & \multicolumn{2}{c}{$\begin{array}{c}\text { Tree Age } \\
\text { (Years) }\end{array}$} & \multicolumn{2}{c}{$\begin{array}{c}\text { Wood Density } \\
\left(\mathbf{k g ~ m}^{-3} \mathbf{)}\right.\end{array}$} & \multicolumn{2}{c}{$\begin{array}{c}\text { Wave Velocity } \\
\left(\mathbf{m ~ s}^{-\mathbf{1}} \mathbf{)}\right.\end{array}$} & \multicolumn{2}{c}{$\begin{array}{c}\text { MOEd } \\
(\mathbf{M P a})\end{array}$} \\
\cline { 2 - 9 } & Mean & SD & Mean & SD & Mean & SD & Mean & SD \\
\hline Beech pure & 69 & 41 & 658 & 28.4 & 3841.7 & 382.4 & 9523.2 & 1738.1 \\
Pine pure & 97 & 38 & 562 & 27.6 & 3823.4 & 427.5 & 8056.6 & 1358.2 \\
MBP-B & 127 & 33 & 653 & 30.1 & 4253.0 & 349.3 & 11583.0 & 2212.6 \\
MBP-P & 103 & 21 & 555 & 25.2 & 4066.4 & 370.6 & 8999.8 & 2132.6 \\
\hline
\end{tabular}


Tree age differed between the pure European beech plots (on average 69 years) and the European beech trees sampled in the mixed-species plots (on average 127 years) (Table 3). By contrast, Calabrian pines occurring in the pure and mixed-species plots revealed no significant differences in tree age (on average 100 years).

For both tree species, MOEd values were significantly higher in MBP than in BP and PP, as confirmed by the Mann-Whitney test applied for independent-samples (Figure 1). MOEd was 21.6\% and $10.7 \%$ higher in MBP than in BP and PP, respectively. Further, considering the different diameter classes investigated, MOEd values were always higher in MBP than in BP and PP.

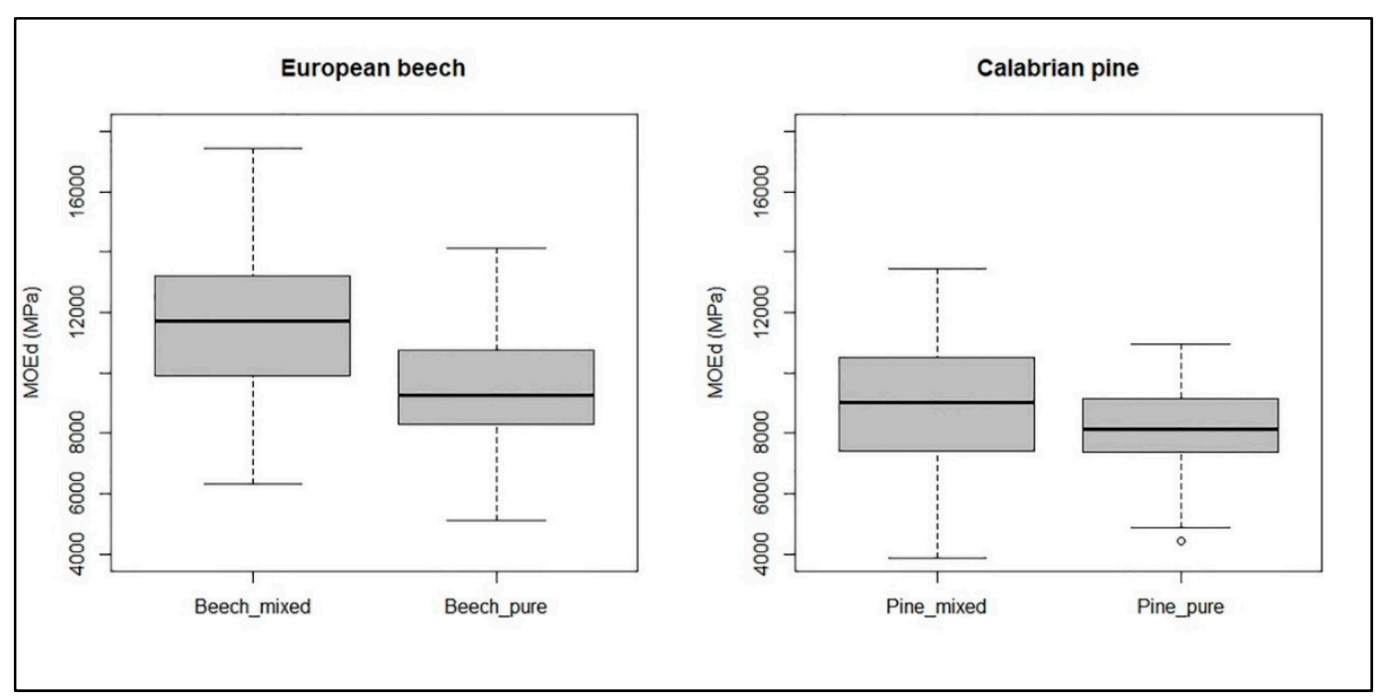

Figure 1. MOEd values in the pure and mixed-species stands for European beech (Mann-Whitney Test, $Z=-6.491, p<0.001$ ) and Calabrian Pine (Mann-Whitney Test, $Z=-3.134, p<0.010$ ).

Analysis of variance (ANOVA) showed a significant effect of the diameter classes on MOEd for BP and PP. As the diameter classes are not independent, the Kruskal-Wallis test was also used [64], which confirmed the significant effect of the diameter classes on MOEd. MOEd decreased as tree DBH increased, with significant differences observed between the smallest and the largest diameter classes. On the contrary, no significant differences were observed in MBP (Figure 2). The mixture of species had the effect of aligning MOEd values, both for European beech and Calabrian pine, making wood quality more uniform for each diameter class. In contrast, in the pure stands, MOEd values were significantly lower than in MBP, also varying significantly as tree DBH increased. 


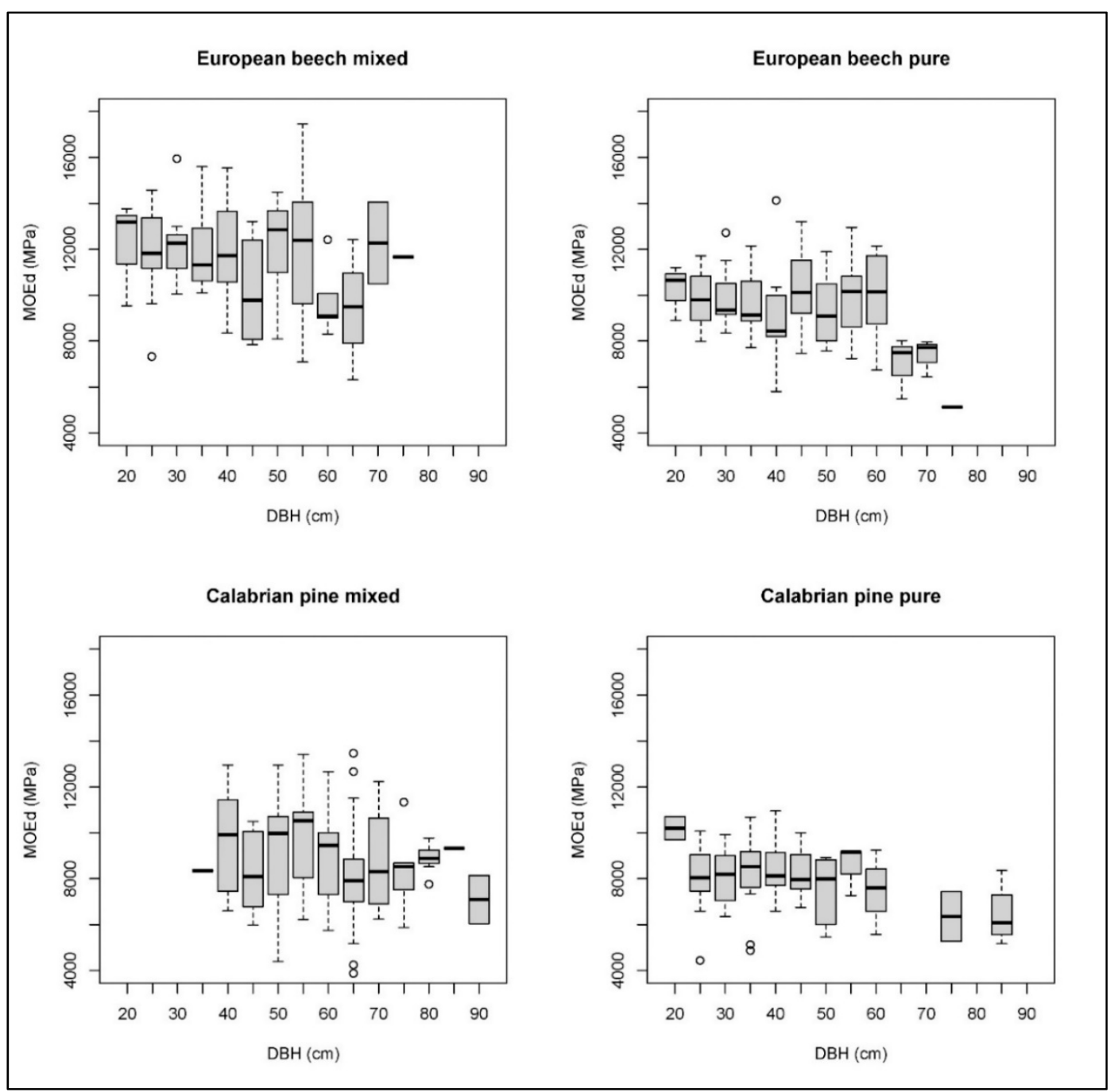

Figure 2. Dynamic modulus of elasticity (MOEd) in relation to the diameter classes for European beech and Calabrian pine growing in the pure and mixed-species stands. European beech in the mixed-species stand: $\mathrm{F}_{12 ; 18}=1.255, p<0.322$; for European beech in the pure stand: $\mathrm{F}_{12 ; 18}=2.461, p<0.050$; Calabrian pine in the mixed-species stand: $\mathrm{F}_{12 ; 18}=0.774, p<0.669$; Calabrian pine in the pure stand: $\mathrm{F}_{11 ; 19}=2.621$, $p<0.050$.

Figure 3 shows the BAI values obtained for European beech and Calabrian pine. In general, BAI increased over time (at least up to a determined year) in both species. Overall, trees revealed higher BAI in MBP than in BP and PP. However, until 1980, BAI values of European beech growing in mixture were always higher than in BP. Later, a similar trend was observed, until 1990. In the last period (1990-2016), BAI values were again higher in MBP. In the period 1900-2016, BAI always increased in MBP, while it gradually decreased in BP, from 1990. For Calabrian pine, BAI values were higher in MBP than in PP, considering the period 1900-1960. Later, for about 20 years (1960-1980), an opposite trend was observed, with a higher BAI in PP. Furthermore, for 1980-2016, a consistent decrease of BAI values was observed for Calabrian pine, both in MBP and PP. 


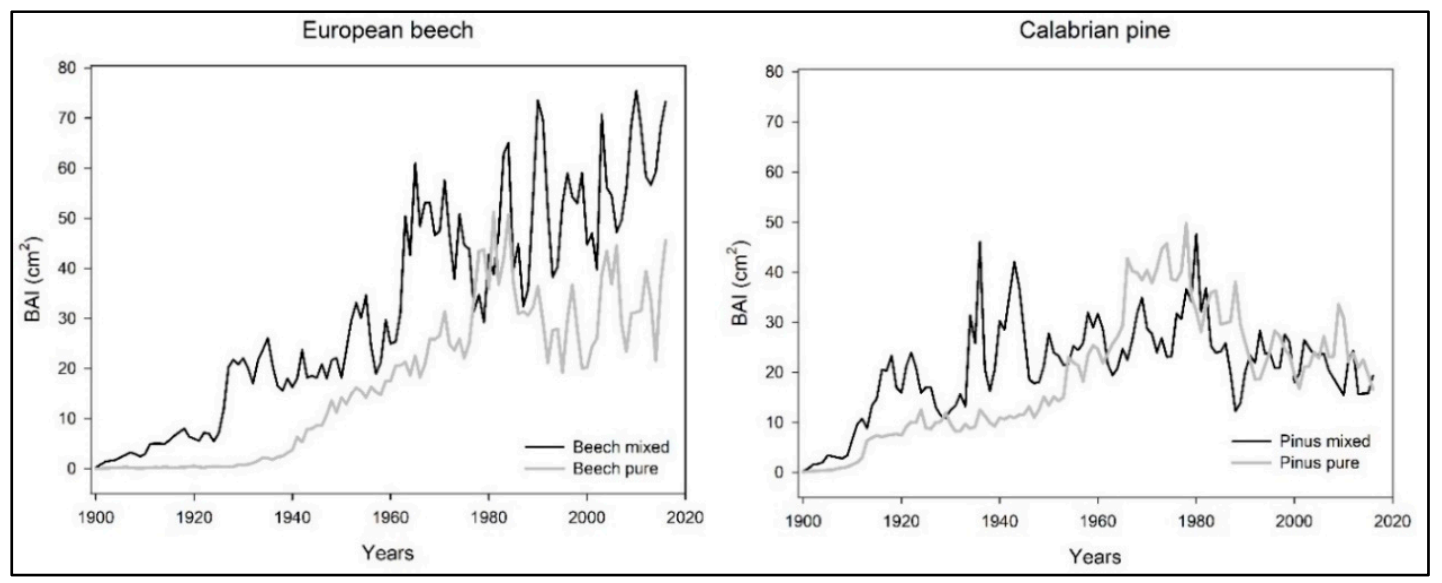

Figure 3. BAI values for European beech and Calabria pine growing in the pure and mixed-species stands. Values were considered starting from 1900.

Figure 4 reports both the variability and the average of BAI values for European beech and Calabrian pine growing in the pure and mixed-species stands. For European beech, the BAI variability was higher in MBP, while for Calabrian pine in PP. European beech growing in mixture had a significantly higher BAI values than in BP $\left(+65 \%, 30.6 \mathrm{vs} .18 .5 \mathrm{~cm}^{2}\right.$, on average, $p$-value $\left.<0.001\right)$. Yet, Calabrian pine growing in mixture revealed higher BAI values than in $\mathrm{PP}$, although not significantly $\left(+11 \%, 21.1\right.$ vs. $19.1 \mathrm{~cm}^{2}$, on average, $p$-value $\left.=0.0563\right)$.

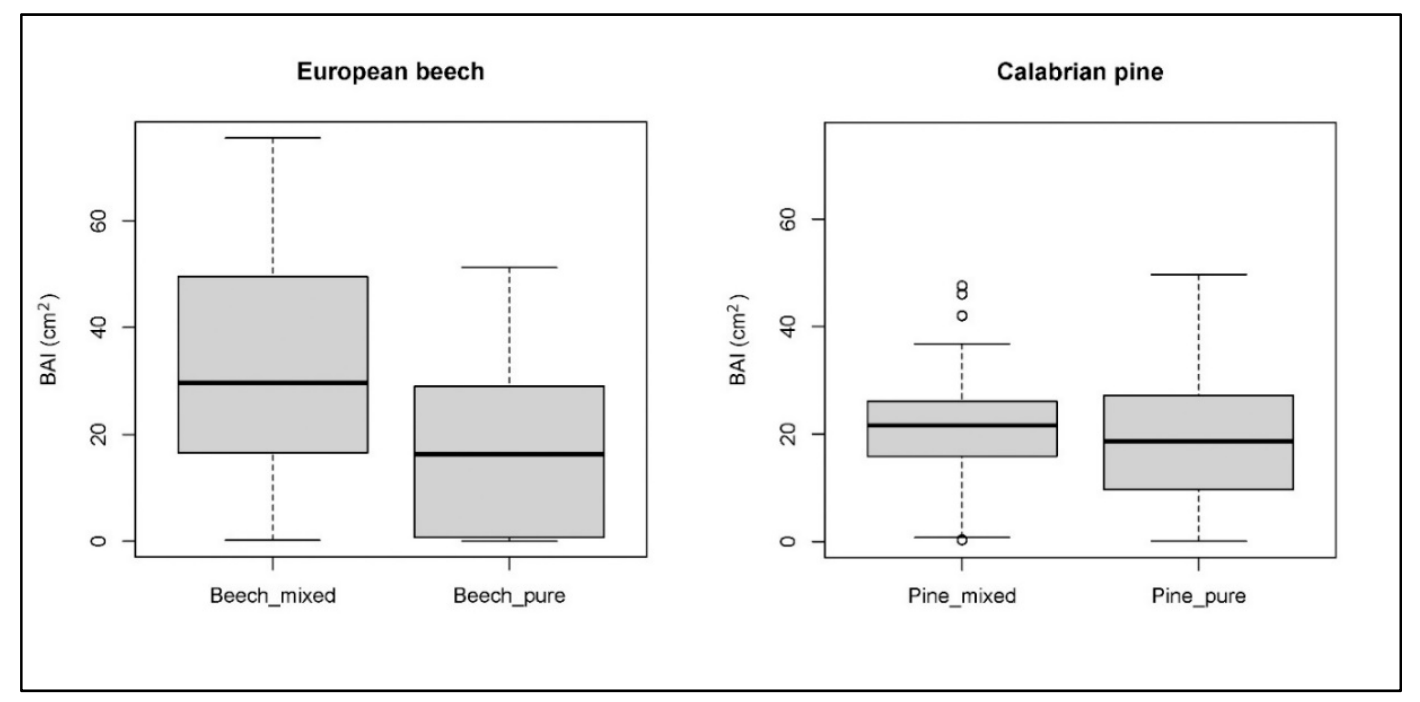

Figure 4. BAI values (mean values) in the pure and mixed-species stands for European beech (linear mixed-effect, $p<0.05, R^{2}=0.437$; Mann-Whitney Test, $Z=-4.345, p<0.0001$ ) and Calabrian pine (linear mixed-effect, $p=0.271, R^{2}=0.078$; Mann-Whitney Test, $Z=-1.928, p=0.0563$ ).

In Table 4, results obtained through the application of the linear mixed model are shown. The site identifier was considered as a random effect. The mixture significantly influenced European beech $(p=0.015)$, but not Calabrian pine $(p=0.601)$. 
Table 4. Values achieved with the application of the linear mixed-effect model, considering the "triplet" as random effect. The influences of the fixed effects (BA\%, RP) on the response variables "basal area increment" (BAI) and "dynamic modulus of elasticity" (MOEd) were examined. Significant variables are reported in bold.

\begin{tabular}{ccccc}
\hline Model & Value & $t$-Value & $p$-Value & $\boldsymbol{R}^{\mathbf{2}}$ \\
\hline European beech (BAI) & & & & 0.502 \\
Intercept & 17.623 & 7.720 & $<0.0001$ & \\
Mix (BA) & $\mathbf{0 . 3 5 8}$ & $\mathbf{4 . 0 4 7}$ & $\mathbf{0 . 0 1 5 5}$ & 0.015 \\
Calabrian pine (BAI) & & & & \\
Intercept & 19.299 & 8.126 & $<0.0001$ & 0.278 \\
Mix (BA) & 0.028 & 0.567 & 0.6009 & \\
European beech (MOEd) & & & & \\
Intercept & 5114.401 & 4.191 & 0.0000 & \\
RP & $\mathbf{2 1 0 . 2 5 2}$ & $\mathbf{4 . 1 1 9}$ & $\mathbf{0 . 0 0 0 1}$ & \\
Mix (BA) & $\mathbf{7 6 . 4 3 4}$ & $\mathbf{3 . 3 5 3}$ & $\mathbf{0 . 0 2 8 5}$ & \\
Calabrian pine (MOEd) & & & & \\
Intercept & 6487.034 & 6.291 & $<0.0001$ & \\
RP & 83.52 & 1.833 & 0.0684 & \\
Mix (BA) & 23.23 & 2.079 & 0.1061 & \\
\hline
\end{tabular}

Figure 5 shows the values of the recruitment period (RP) for European beech and Calabrian pine, which invariably decreased as DBH increased. For European beech, RP was lower in MBP than in BP, though with lessening differences as DBH increased. Calabrian pine growing in PP had, for the first diameter classes, a slightly lower RP than in MBP, at least for the first diameter classes. Then, the trend was the opposite and the differences tended to increase, though not for the DBH of about $90 \mathrm{~cm}$.

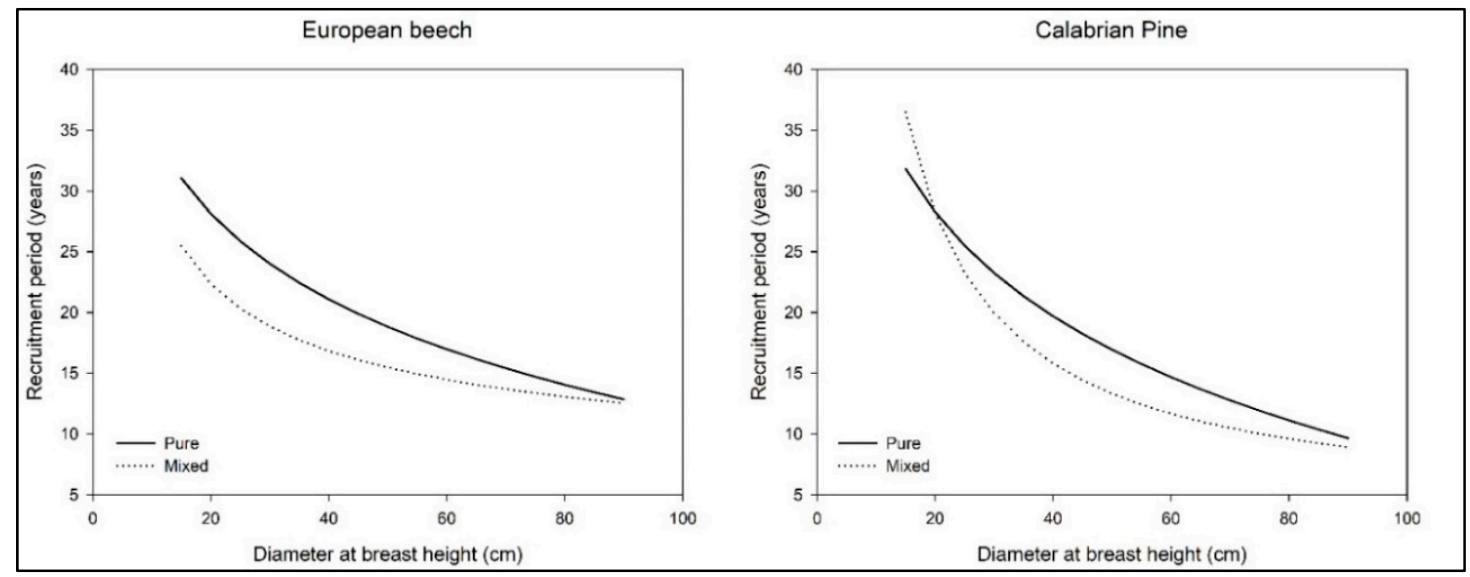

Figure 5. Recruitment period obtained for European beech and Calabrian pine growing in the pure and mixed-species stands. It indicates the number of years needed to pass from a diameter class xi to the largest class $x i+5 \mathrm{~cm}$.

Finally, in Figure 6, variations of MOEd as RP changes are shown. In each stand, MOEd tended to rise as RP increased, even if it revealed higher values in MBP than in BP and PP. In addition, the relationship between MOEd and RP was stronger in MBP, for both species. However, the analyses of the linear mixed-effects model underlined that only for European beech, RP $(p<0.0001)$ and the mixing effect $(p=0.0285)$ had a significant role, explaining the largest proportion of MOEd variation (Table 3). On the contrary, for Calabrian pine, RP $(p=0.0684)$ and the mixing effect $(p=0.1061)$ had marginal effects on MOEd. 


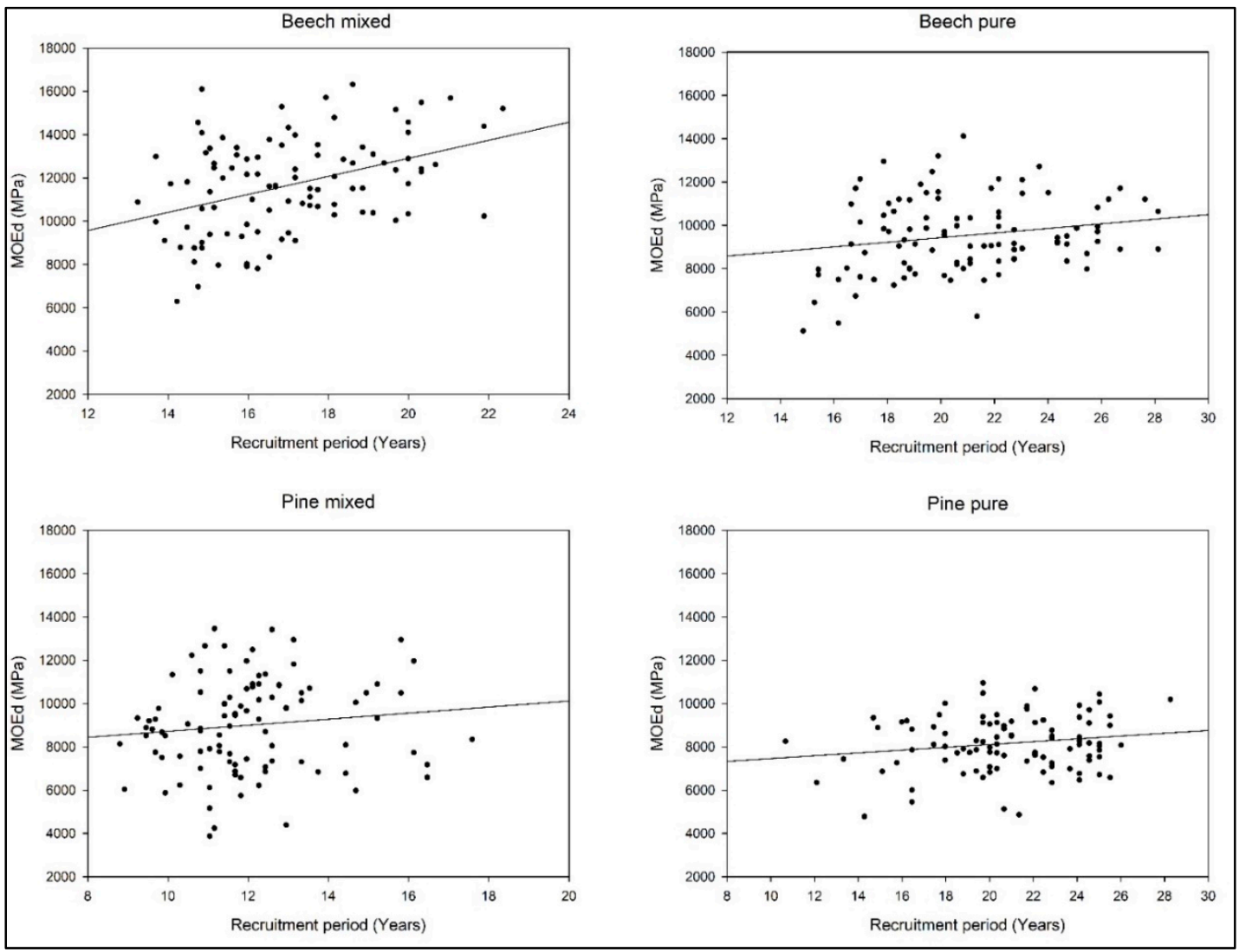

Figure 6. Dynamic modulus of elasticity (MOEd) in relation to the recruitment period for European beech and Calabrian pine growing in the pure and mixed-species stands.

\section{Discussion}

Results demonstrated how the mixture effect influenced both wood quality and tree ring widths. In both the pure and mixed-species stands, MOEd values were above the minimum quality threshold (MOEd > $9000 \mathrm{MPa}$ ) [65]. However, in the mixed-species plots, MOEd values were always higher than in the corresponding pure plots. This difference was more evident for European beech (11583 vs. 9523) than for Calabrian pine ( 8999 vs. 8056). Tree age differed between European beech trees sampled in the pure and mixed species plots, which might have played a role in determining differences in MOEd values. In the case of Calabrian pine, the differences in MOEd values are less evident, though significant. As a matter of fact, tree age did not differ between trees sampled in the pure and mixed-species plots.

Eventually, effects on MOEd exerted by the other parameters related to the stand structure (stand density, basal area, stand volume) could be excluded, since the parameters did not differ significantly between the pure and mixed-species stands. Several studies showed that, considering other variables being equal (stand density, stand volume, etc.), the mixture effect could have a role in improving the resistance and resilience of trees in comparison with the corresponding monocultures [21-24]. Yet, the mixed-species stands could also be more productive than the corresponding monocultures [26].

Therefore, even with some limitations, a mixture of European beech and Calabrian pine might have a positive effect on MOEd, not only at the stand level, but also considering the different diameter classes. In fact, in the mixed stands, the MOEd values were similar for all the diameter classes, in both species. On the contrary, in the pure stands, we observed a decrease in wood quality as the tree DBH increased. A combination of a light demanding tree species with one more shade tolerant was probably the foundation of these results. In other studies, mixed-species stands were found to show higher light interception and light-use efficiency in comparison with monocultures [10,66-68]. Promoting the 
coexistence of these two species in the present environmental conditions might improve the quality of wood materials, regardless of the size of trees from which the assortments are obtained.

The MOEd values, strongly related to wood density and acoustic velocity, indicated an overall higher mechanical stability attained in the mixed-species stands. In fact, wood density is correlated with timber strength [69], hardness and abrasiveness [48]. Therefore, mixing these species might provide higher mechanical resistance to natural disturbances, such as windstorms, and higher carbon sequestration potential in these Mediterranean mountain forest ecosystems. It must be pointed out that Pretzsch and Rais [49] observed that the wood strength and stiffness could be lower in complex forests than in homogeneous monocultures, where tree size and shape development progress more continuously. Yet, Torquato et al. [70], in black spruce forests in Canada, detected lower strength and stiffness properties in complex stands.

Growing in mixtures induced an increase in tree biomass production, particularly for European beech, while differences between the pure and mixed-species stands were not significant for Calabrian pine. In European beech, although environmental conditions did not differ between stands, BAI was significantly higher in mixture than in monoculture. However, differences between the pure and mixed-species stands in tree age might also have affected BAI trends. The identification of growth trends and attribution of their drivers are not easy tasks, and require long-term and spatially-representative experiments to control the effect of tree size and age, avoiding sampling biases at the various scales. Indeed, heterogeneous crown structures and the tree size of mixed-species stands might facilitate the penetration of light into the lower canopy layers [10]. In the studied stands, European beech could take advantage of growing underneath the relatively transparent canopy of Calabrian pine. On the other hand, European beech in pure and dense stands develops homogeneous canopy cover, having high shade tolerance and large canopy expansion. Indeed, European beech growing in monocultures showed low self-tolerance [71,72], resulting in severe intraspecific competition due to high lateral canopy expansion [73]. Moreover, other studies reported beneficial effects on European beech productivity from growing in mixture [74,75]. Condes et al. [76] reported that the productivity of pine-beech admixtures was generally greater than in the corresponding pure stands. In light of this, admixture of European beech with Calabrian pine might, therefore, reduce competition or even increase facilitation processes in this Mediterranean mountain environment. Nevertheless, Conte et al. [16] observed higher productivity in the pure than mixed-species stands of European beech and Scots pine, in Alpine environmental conditions. These discrepancies suggest caution in generalizing the positive effects on European beech productivity from growing admixed with pine species.

However, the complexity of the species interactions, which depends on stand development stage, stand density and site conditions [26], suggests caution in generalizing these results, since other studies reported opposite patterns [77]. Equal productivity at the stand level might not necessarily indicate a neutral behaviour of the two species co-occurring in the mixed-species stands. In fact, species-specific reactions, at individual or stand level, might counteract and cancel each other with respect to the stand level productivity [74]. Behind overyielding or underyielding of mixed-species in comparison with nearby pure stands, as revealed in this study for Calabrian pine and European beech, there is always a modified supply and uptake, or different use-efficiency, of available resources [24,26,78]. Zhang et al. [21] reported that beneficial effects of admixing provided an overall $25 \%$ increase in productivity across forest types and a 12\% increase at European scale in Scots pine-European beech mixtures [10]. Nevertheless, the mechanisms that might promote complementarity effects, leading to increased productivity in pine-beech mixtures, are poorly understood, despite the frequent occurrence and economic importance of these forest types [10].

Values of BAI in Calabrian pine and European beech mixtures, of both species, were generally greater than in the corresponding pure stands, although significant only in the case of European beech. European beech, especially in the mixed-species stands, had a constantly increasing BAI in the investigated time-span, although alternating years of little stem radial growth and years of great stem radial growth. On the contrary, Calabrian pine revealed a decrease in BAI values in the last 30-40 years. 
Several studies reported that the inter-annual tree growth variability and its dependence on climatic conditions might be modulated by species composition [4,79-81]. A positive effect of species diversity on stand productivity, due to complementarity effects, might result in a greater size heterogeneity, with unknown consequences on the provision of goods and services in pure vs. mixed-species forests. A reduction in size asymmetry and growth inequality for European beech in mixture with Scots pine was related to the complementary light ecology of the associated species [10].

At the stand level, light absorption of admixed light demanding and shade tolerant species might benefit from light-related interactions, including canopy structure, stand density, tree size, crown architecture, and allometric relationships [82,83]. Nevertheless, in the present Mediterranean environment, although light-related interactions might contribute to the mixing effect on tree growth for Calabrian pine, water- and/or nutrient-related interactions might dominate in the mixing effect on tree growth for European beech [84]. Especially for European beech, we showed that the variability of BAI was higher in the mixed-species vs. the pure stands. Although this variability might have a minor role in determining the strength and stiffness of structural timber [49], it might still affect wood properties, such as the dimensional stability. Nevertheless, we may confirm that (i) wood quality was higher in the mixed-species than pure stands, (ii) wood quality was dependent on tree growth patterns and that (iii) the longer a tree took to pass from one diameter class to the next, the better was the wood quality. However, Genet et al. [85] stated that the way in which tree ring widths and ring wood density are related to each other would depend on whether the tree is a conifer, ring-porous hardwood, or diffuse-porous hardwood species.

We found a positive relationship between final growth time and MOEd, in both species. However, while for European beech MOEd was significantly dependent on tree growth (expressed as recruitment period), this relationship was not significant for Calabrian pine. In these relationships, MOEd was higher in the mixed-species than pure stands, for both species. Again, this might depend on species-specific growth patterns, as well as on technological wood features. However, it must be pointed out that wood quality of coniferous trees, in comparison with broadleaved species, might be strongly influenced by forest management practices. In fact, several studies on conifers [59,86-90], including Calabrian pine [44], showed a reduction in wood quality with increasing spacing and thinning.

Admixture of Calabrian pine and European beech might improve adaptation to rainy winters and dry summers of the Mediterranean climate, increasing both tree growth and wood quality, especially for European beech. Several studies showed that mixed-species forests might be more productive and resistant to disturbances, including drought, than corresponding pure stands [4,79], though contrasting evidence was also reported [14,16]. In particular, European beech populations from marginal ecological conditions were found more resistant to drought than those from the core of the distribution range [91-93], and their admixture with co-occurring drought-tolerant conifers might serve as benchmark for selecting resilient tree species combinations. Additional insight into the effect of tree species mixture on wood quality is required to support the entire wood supply chain, from the integration of wood quality in forest inventories to silvicultural guidelines for decision support tools. In fact, although structure and function of mixed-species stands are relevant for their role as supporting services in Mediterranean mountain forests, such as biodiversity conservation and soil protection, the consequence of structural heterogeneity in admixture on wood quality requires greater consideration in the future.

\section{Conclusions}

In the present study, the admixture of Calabrian pine and European beech increased stand productivity, particularly for European beech, and improved wood quality. Nevertheless, caution is still needed in drawing general conclusions on the mixture effect on wood quality and stand productivity, in marginal environmental conditions. Nevertheless, European beech and Calabrian pine co-occurring in forest stands of Southern Italy should be managed with the aim of improving the overall quality of wood, which could be promoted by mixing these species. Although any generalization could 
be misleading, the admixture of tree species in these harsh environments might better maintain forest stability, ensuring also woody products of better quality. These results, though related to marginal environmental conditions, could be significant to implement and support climate-smart measures for managing Mediterranean mountain forests.

Author Contributions: Conceptualization, D.R., P.A.M., G.M. and F.L.; Data curation, D.R. and G.M.; Formal analysis, D.R., P.A.M., G.M., G.Z., R.T. and F.L.; Investigation, D.R. and G.M.; Methodology, D.R., P.A.M., R.T., and F.L.; Resources, R.T. and G.Z.; Writing-original draft, D.R., P.A.M., R.T. and F.L.; Writing—review \& editing, P.A.M., R.T. and F.L. All authors have read and agreed to the published version of the manuscript.

Funding: This research was funded by the Aspromonte National Park.

Acknowledgments: We are grateful to the Aspromonte National Park for the support given to realize this study. The research is linked to activities conducted within the COST (European Cooperation in Science and Technology) Action CLIMO (Climate-Smart Forestry in Mountain Regions-CA15226) financially supported by the EU Framework Programme for Research and Innovation HORIZON 2020, and the Progetto bilaterale di Grande Rilevanza Italy-Sweden "Natural hazards in future forests: how to inform climate change adaptation".

Conflicts of Interest: The authors declare no conflict of interest.

\section{References}

1. Gamfeldt, L.; Snäll, T.; Bagchi, R.; Jonsson, M.; Gustafsson, L.; Kjellander, P.; Ruiz-Jaen, M.C.; Fröberg, M.; Stendahl, J.; Philipson, C.D.; et al. Higher levels of multiple ecosystem services are found in forests with more tree species. Nat. Commun. 2013, 4, 1340. [CrossRef] [PubMed]

2. van der Plas, F.; Manning, P.; Soliveres, S.; Allan, E.; Scherer-Lorenzen, M.; Verheyen, K.; Wirth, C.; Zavala, M.A.; Ampoorter, E.; Baeten, L.; et al. Biotic homogenization can decrease landscape-scale forest multifunctionality. Proc. Natl. Acad. Sci. USA 2016, 113, 3557-3562. [CrossRef] [PubMed]

3. Cudlín, P.; Klopčič, M.; Tognetti, R.; Máliš, F.; Alados, C.L.; Bebi, P.; Grunewald, K.; Zhiyanski, M.; Andonowski, V.; La Porta, N.; et al. Frans Emil Wielgolaski Drivers of treeline shift in different European mountains. Clim. Res. 2017, 73, 135-150. [CrossRef]

4. Pretzsch, H.; Bielak, K.; Bruchwald, A.; Dieler, J.; Dudzinska, M.; Erhart, H.P.; Jensen, A.M.; Johannsen, V.K.; Kohnle, U.; Nagel, J.; et al. Mischung und Produktivität von Waldbeständen. Ergebnisse langfristiger ertragskundlicher Versuche. Allgemeine Forst-und Jagdzeitung 2013, 184, 177-196.

5. Yachi, S.; Loreau, M. Does complementary resource use enhance ecosystem functioning? A model of light competition in plant communities. Ecol. Lett. 2007, 10, 54-62. [CrossRef]

6. Piotto, D. A meta-analysis comparing tree growth in monocultures and mixed plantations. For. Ecol. Manag. 2008, 255, 781-786. [CrossRef]

7. Morin, X.; Fahse, L.; Scherer-Lorenzen, M.; Bugmann, H. Tree species richness promotes productivity in temperate forests through strong complementarity between species. Ecol. Lett. 2011, 14, 1211-1219. [CrossRef]

8. Paquette, A.; Messier, C. The effect of biodiversity on tree productivity: From temperate to boreal forests. Glob. Ecol. Biogeogr. 2011, 20, 170-180. [CrossRef]

9. Pretzsch, H.; Schütze, G.; Uhl, E. Resistance of European tree species to drought stress in mixed versus pure forests: Evidence of stress release by inter-specific facilitation. Plant Biol. 2013, 15, 483-495. [CrossRef]

10. Pretzsch, H.; Schütze, G. Effect of tree species mixing on the size structure, density and yield forest stands. Eur. J. For. Res. 2015, 135, 1-22. [CrossRef]

11. Jucker, T.; Bouriaud, O.; Avacaritei, D.; Coomes, D.A. Stabilizing effects of diversity on aboveground wood production in forest ecosystems: Linking patterns and processes. Ecol. Lett. 2014, 17, 1560-1569. [CrossRef] [PubMed]

12. Metz, J.; Annighofer, P.; Schall, P.; Zimmermann, J.; Kahl, T.; Schulze, E.D. Site-adapted admixed tree species reduce drought susceptibility of mature European beech. Glob. Chang. Biol. 2016, 22, 903-920. [CrossRef] [PubMed]

13. Liang, J.; Crowther, T.W.; Picard, N.; Wiser, S.; Zhou, M.; Alberti, G.; Schulze, E.D.; McGuire, A.D.; Bozzato, F.; Pretzsch, H.; et al. Positive biodiversity-productivity relationship predominant in global forests. Science 2016, 354, 196. [CrossRef] [PubMed] 
14. Grossiord, C.; Granier, A.; Gessler, A.; Jucker, T.; Bonal, D. Does drought influence the relationship between biodiversity and ecosystem functioning in boreal forests? Ecosystems 2014, 17, 394-404. [CrossRef]

15. Merlin, M.; Perot, T.; Perret, S.; Korboulewsky, N.; Vallet, P. Effects of stand composition and tree size on resistance and resilience to drought in sessile oak and Scots pine. For. Ecol. Manag. 2015, 339, 22-33. [CrossRef]

16. Conte, E.; Lombardi, F.; Battipaglia, G.; Palombo, C.; Altieri, S.; La Porta, N.; Marchetti, M.; Tognetti, R. Growth dynamics, climate sensitivity and water use efficiency in pure vs. mixed pine and beech stands in Trentino (Italy). For. Ecol. Manag. 2018, 409, 707-718. [CrossRef]

17. Gebauer, T.; Horna, V.; Leuschner, C. Canopy transpiration of pure and mixed forest stands with variable abundance of European beech. J. Hydrol. 2012, 442, 2-14. [CrossRef]

18. IPCC. Meeting report of the intergovernmental panel on climate change expert meeting on mitigation, sustainability and climate stabilization scenarios. In IPCC Working Group III Technical Support Unit; Shukla, P.R.J., Skea, R., van Diemen, K., Calvin, Ø., Christophersen, F., Creutzig, J., Eds.; Imperial College London: London, UK, 2017.

19. Hanewinkel, M.; Cullmann, D.; Schelhaas, M.J.; Nabuurs, G.J.; Zimmermann, N.E. Climate change may cause severe loss in economic value of European forestland. Nat. Clim. Chang. 2013, 3, 204-207. [CrossRef]

20. Altieri, V.; De Franco, S.; Lombardi, F.; Marziliano, P.A.; Menguzzato, G.; Porto, P. The role of silvicultural systems and forest types in preventing soil erosion processes in mountain forests: A methodological approach using cesium-137 measurements. J. Soils Sediments 2018, 18, 1-10. [CrossRef]

21. Zhang, Y.; Chen, H.Y.H.; Reich, P.B. Forest productivity increases with evenness, species richness and trait variation: A global meta-analysis. J. Ecol. 2012, 100, 742-749. [CrossRef]

22. Kanowski, J.; Catterall, C.P.; Wardell-Johnson, G.W. Consequences of broadscale timber plantations for biodiversity in cleared rainforest landscapes of tropical and subtropical Australia. For. Ecol. Manag. 2005, 208, 359-372. [CrossRef]

23. Petit, B.; Montagnini, F. Growth in pure and mixed plantations of tree species used in reforesting rural areas of the humid region of Costa Rica, Central America. For. Ecol. Manag. 2006, 233, 338-343. [CrossRef]

24. Richards, A.E.; Forrester, D.I.; Bauhus, J.; Scherer-Lorenzen, M. The influence of mixed tree plantations on the nutrition of individual species: A review. Tree Physiol. 2010, 30, 1192-1208. [CrossRef]

25. Bielak, K.; Dudzinska, M.; Pretzsch, H. Mixed stands of Scots pine (Pinus sylvestris L.) and Norway spruce [Picea abies (L.) Karst] can be more productive than monocultures. Evidence from over 100 years of observation of long-term experiments. For. Syst. 2014, 23, 573. [CrossRef]

26. Forrester, D.I. The spatial and temporal dynamics of species interactions in mixed-species forests: From pattern to process. For. Ecol. Manag. 2014, 312, 282-292. [CrossRef]

27. Petráš, R.; Mecko, J.; Bošelâ, M.; Šebeň, V. Wood quality and value production in mixed fir-spruce-beech stands: Long-term research in the Western Carpathians. For. J. 2016, 62, 98-104. [CrossRef]

28. Magin, R. Ertragskundliche Untersuchungen in montanen Mischwäldern. Forstwissenschaftliches Centralblatt 1954, 73, 103-113. [CrossRef]

29. Kennel, R. Untersuchungen über die Leistung von Fichte und Buche im Reinund Mischbestand. Sauerländer 1965, 136, 149-161.

30. Kennel, R. Soziale Stellung, Nachbarschaft und Zuwachs. Forstwissenschaftliches Centralblatt 1966, 85, $193-204$. [CrossRef]

31. Hausser, K.; Troeger, R. Beitrag zur Frage der Massen und Wertleistung gepflanzter Weisstannen und Fichtenbestände auf gleichen Standorten. Allgemeine Forst-und Jagdzeitung 1967, 138, 150-157.

32. Mitscherlich, G. Ertragskundlich-ökologische Untersuchungen im Rein-und Mischbestand. Mitteilungen der Forstlichen Bundes-Versuchsanstalt 1967, 77, 9-35.

33. Hink, V. Das Wachstum von Fichte und Tanne auf den wichtigsten Standortseinheiten des Einzelwuchsbezirks "Flächenschwarzwald" (Südwürtemberg-Hohenzollern). Allgemeine Forst-und Jagdzeitung 1972, 143, 80-85.

34. Mettin, C. Betriebswirtschaftliche und ökologische Zusammenhänge zwischen Standortskraft und Leistung in Fichtenreinbeständen und Fichten Buchen-Mischbeständen. Allgemeine Forst-und Jagdzeitung 1985, 40, 803-810.

35. Kramer, H. Waldwachstumslehre (Forest Growth and Yield Science); Paul Parey: Hamburg, Germany, $1988 ;$ p. 374. (In German)

36. Pretzsch, H. Forest Dynamics, Growth and Yield: From Measurement to Model; Springer: Berlin, Germany, 2010. 
37. Saha, S.; Kuehne, C.; Kohnle, U.; Brang, P.; Ehring, A.; Geisel, J.; Leder, B.; Muth, M.; Petersen, R.; Peter, J.; et al. Growth and quality of young oaks (Quercus robur and Quercus petraea) grown in cluster plantings in central Europe: A weighted meta-analysis. For. Ecol. Manag. 2012, 283, 106-118. [CrossRef]

38. Liu, C.L.C.; Kuchma, O.; Krutovsky, K.V. Mixed secies versus monocultures in plantation forestry: Development, benefits, ecosystem services and perspectives for the future. Glob. Ecol. Conserv. 2018, 15, e00419. [CrossRef]

39. Chomel, M.; DesRochers, A.; Baldy, V.; Larchevêque, M.; Gauquelin, T. Non-additive effects of mixing hybrid poplar and white spruce on aboveground and soil carbon storage in boreal plantations. For. Ecol. Manag. 2014, 328, 292-299. [CrossRef]

40. Battipaglia, G.; Pelleri, F.; Lombardi, F.; Altieri, S.; Vitone, A.; Conte, E.; Tognetti, R. Effects of associating Quercus robur L. and Alnus cordata Loisel. on plantation productivity and water use efficiency. For. Ecol. Manag. 2017, 391, 106-114. [CrossRef]

41. Kelty, M.J. The role of species mixtures in plantation forestry. For. Ecol. Manag. 2006, 233, 195-204. [CrossRef]

42. Machado, J.S.; Louzada, J.L.; Santos, A.J.A.; Nunes, L.; Anjos, O.; Rodrigues, J.; Simoes, R.M.S.; Pereira, H. Variation of wood density and mechanical properties of blackwood (Acacia melanoxylon r. Br.). Mater. Des. 2014, 56, 975-980. [CrossRef]

43. Pretzsch, H.; Schütze, G. Transgressive overyielding in mixed compared with pure stands of Norway spruce and European beech in Central Europe: Evidence on stand level and explanation on individual tree level. Eur. J. For. Res. 2009, 128, 183-204. [CrossRef]

44. Russo, D.; Marziliano, P.A.; Macri, G.; Proto, A.R.; Zimbalatti, G.; Lombardi, F. Does thinning intensity affect wood quality? An analysis of Calabrian Pine in Southern Italy using a non-destructive acoustic method. Forests 2019, 30, 303. [CrossRef]

45. Guntekin, G.; Emiroglu, Z.G.; Yolmaz, T. Prediction of bending properties for Turkish red pine (Pinus brutia Ten.) Lumber using stress wave method. Bioresources 2013, 8, 231-237. [CrossRef]

46. Teder, M.; Pilt, K.; Miljan, M.; Lainurm, M.; Kruuda, R. Overview of some non-destructive methods for in-situ assessment of structural timber. In Proceedings of the 3rd International Conference Civil Engineering, Jelgava, Latvia, 12-13 May 2011.

47. Wessels, C.B.; Malan, F.S.; Rypstra, T. A review of measurement methods used on standing trees for the prediction of some mechanical properties of timber. Eur. J. For. Res. 2011, 130, 881-893. [CrossRef]

48. Bacher, M.; Krosek, S. Bending and tension strength classes in European standards. Annals of Warsaw University of Life Sciences-SGGW. For. Wood Tech. 2014, 88, 14-22.

49. Pretzsch, H.; Rais, A. Wood quality in complex forests versus even-aged monocultures: Review and perspectives. Wood Sci. Technol. 2016, 50, 845-880. [CrossRef]

50. Rais, A.; Van de Kuilen, J.W.G. Critical section effect during derivation of settings for grading machines based on dynamic modulus of elasticity. Wood Mater. Sci. Eng. 2015, 4, 189-196. [CrossRef]

51. FAO. World Reference Base for Soil Resources. In International Soil Classification System for Naming Soils and Creating Legends for Soil Maps; World Soil Resources Reports, No. 106; FAO: Roma, Italy, 2014.

52. Ciancio, O.; Iovino, F.; Menguzzato, G.; Nicolaci, A.; Nocentini, S. Structure and growth of a small group selection forest of Calabrian pine in Southern Italy: A hypothesis for continuous cover forestry based on traditional silviculture. For. Ecol. Manag. 2006, 224, 229-234. [CrossRef]

53. Tabacchi, G.; Di Cosmo, L.; Gasparini, P. Aboveground tree volume and phytomass prediction equations for forest species in Italy. Eur. J. For. Res. 2011, 130, 911-934. [CrossRef]

54. Holmes, R.L. Computer-assisted quality control in tree-ring dating and measurement. Tree-Ring Bull. 1983, 43, 69-78.

55. Wang, X. Acoustic measurements on trees and logs: A review and analysis. Wood Sci. Technol. 2013, 47, 965-975. [CrossRef]

56. Vanninen, P.; Ylitalo, H.; Sievanen, R.; Makela, A. Effect of age and site quality on the distribution of biomass in Scots pine (Pinus sylvestris L.). Trees 1996, 10, 231-238. [CrossRef]

57. Vargas-Hernandez, J.; Adams, W.T. Genetic relationships between wood density components and cambial growth rhythm in young coastal Douglas-fir. Can. J. For. Res. 1994, 24, 1871-1876. [CrossRef]

58. Zhembo, L.; Yixing, L.; Haipeng, Y.; Junqi, Y. Measurement of the dynamic modulus of elasticity of wood panels. Front. For. China 2006, 1, 425-430. 
59. Todaro, L.; Macchioni, N. Wood properties of young Douglas-fir in Southern Italy: Results over a 12-year post-thinning period. Eur. J. For. Res. 2011, 130, 251-261. [CrossRef]

60. Zhang, H.; Wang, X.; Su, J. Experimental Investigation of Stress Wave Propagation in Standing Trees. Holzforschung 2011, 65, 743-748. [CrossRef]

61. Krajnc, L.; Farrelly, N.; Harte, A.M. Evaluating Timber Quality in Larger-Diameter Standing Trees: Rethinking the Use of Acoustic Velocity. Holzforschung 2019, 73, 797-806. [CrossRef]

62. Marziliano, P.A.; Menguzzato, G.; Scuderi, A.; Corona, P. Simplified methods to inventory the current annual increment of forest standing volume. iForest 2012, 5, 276-282. [CrossRef]

63. Team, R.C. R: A Language and Environment for Statistical Computing; R Foundation for Statistical Computing: Vienna, Austria, 2016.

64. Zar, J.H. Biostatistical Analysis, 4th ed.; Prentice Hall: Upper Saddle River, NJ, USA, 1999.

65. Detters, A.; Cowell, C.; McKeown, L.; Howard, P. Evaluation of Current Rigging and Dismantling Practices Used in Arboriculture; The Health and Safety Executive: London, UK; The Forestry Commission: Edinburgh, UK, 2008; p. 355.

66. Binkley, D.; Dunkin, K.A.; DeBell, D.; Ryan, M.G. Production and nutrient cycling in mixed plantations of eucalyptus and albizia in Hawaii. For. Sci. 1992, 38, 393-408.

67. Kelty, M.J. Comparative productivity of monocultures and mixed-species stands. In The Ecology and Silviculture of Mixed-Species Forests; Springer: Dordrecht, The Netherlands, 1992; pp. 125-141.

68. Forrester, D.I.; Lancaster, K.; Collopy, J.J.; Warren, C.R.; Tausz, M. Photosynthetic capacity of Eucalyptus globulus is higher when grown in mixture with Acacia mearnsii. Trees 2012, 26, 1203-1213. [CrossRef]

69. Saranpää, P. Wood density and growth. In Wood Quality and Its Biological Basis Blackwell; Biological Sciences Series; Barnett, J.R., Jeronimidis, G., Eds.; CRC Press: Oxford, FL, USA, 2003; pp. 87-113.

70. Torquato, L.P.; Auty, D.; Herândez, R.E.; Duchesne, I.; Pothier, D.; Achim, A. Black spruce trees from fire-origin stands have higher wood mechanical properties than those from older, irregular stands. Can. J. For. Res. 2014, 44, 118-127. [CrossRef]

71. Metz, J.Ô.; Seidel, D.; Schall, P.; Scheffer, D.; Schulze, E.D.; Ammer, C. Crown modeling by terrestrial laser scanning as an approach to assess the effect of aboveground intra- and interspecific competition on tree growth. For. Ecol. Manag. 2013, 310, 275-288. [CrossRef]

72. Pretzsch, H.; Biber, P. A re-evaluation of Reineke's rule and stand density index. For. Sci. 2005, 51, 304-320.

73. Pretzsch, H. Species-specific allometric scaling under self-thinning: Evidence from long-term plots in forest stands. Oecologia 2006, 146, 572-583. [CrossRef] [PubMed]

74. Pretzsch, H.; Block, J.; Dieler, J.; Dong, P.H.; Kohnle, U.; Nagel, J.; Spellmann, H.; Zingg, A. Comparison between the productivity of pure and mixed stands of Norway spruce and European beech along an ecological gradient. Ann. For. Sci. 2010, 67, 712. [CrossRef]

75. Pretzsch, H.; Bielak, K.; Block, J.; Bruchwald, A.; Dieler, J.; Ehrhart, H.P.; Kohnle, U.; Nagel, J.; Spellmann, H.; Zasada, M.; et al. Productivity of mixed versus pure stands of oak (Quercus petraea (Matt.) Liebl. and Quercus robur L.) and European beech (Fagus sylvatica L.) along an ecological gradient. Eur. J. For. Res. 2013, 132, 263-280. [CrossRef]

76. Condés, S.; del Río, M.; Sterba, H. Mixing effect on volume growth of Fagus sylvatica and Pinus sylvestris is modulated by stand density. For. Ecol. Manag. 2013, 292, 86-95. [CrossRef]

77. Zeller, L.; Ammer, C.; Annighöfer, P.; Biber, P.; Marshall, J.; Schütze, G.; del Río Gaztelurrutia, M.; Pretzsch, H. Tree ring wood density of Scots pine and European beech lower in mixed-species stands compared with monocultures. For. Ecol. Manag. 2017, 400, 363-374. [CrossRef]

78. Binkley, D.; Stape, J.L.; Ryan, M.G. Thinking about efficiency of resource use in forests. For. Ecol. Manag. 2004, 193, 5-16. [CrossRef]

79. Lebourgeois, F.; Gomez, N.; Pinto, P.; Mérian, P. Mixed stands reduce Abies alba tree-ring sensitivity to summer drought in the Vosges mountains, western Europe. For. Ecol. Manag. 2013, 303, 61-71. [CrossRef]

80. Del Río, M.D.; Schütze, G.; Pretzsch, H. Temporal variation of competition and facilitation in mixed species forests in Central Europe. Plant Biol. 2014, 16, 166-176. [CrossRef]

81. Del Río, M.; Pretzsch, H.; Ruíz-Peinado, R.; Ampoorter, E.; Annighöfer, P.; Barbeito, I.; Bielak, K.; Brazaitis, G.; Coll, L.; Drössler, L. Species interactions increase the temporal stability of community productivity in Pinus sylvestris-Fagus sylvatica mixtures across Europe. J. Ecol. 2017, 105, 1032-1043. [CrossRef] 
82. Ellenberg, H.; Leuschner, C. Vegetation Mitteleuropas Mit den Alpen in Ökologischer, Dynamischer und Historischer Sicht; Eugen Ulmer Stuttgart: Nürtingen, Germany, 2010.

83. Pretzsch, H. The Effect of Tree Crown Allometry on Community Dynamics in Mixed-Species Stands versus Monocultures. A Review and Perspectives for Modeling and Silvicultural Regulation. Forests 2019, 10, 810. [CrossRef]

84. Forrester, D.I.; Ammer, C.; Annighöfer, P.J.; Barbeito, I.; Bielak, K.; Bravo-Oviedo, A.; Coll, L.; del Río, M.; Drössler, L.; Heym, M.; et al. Effects of crown architecture and stand structure on light absorption in mixed and monospecific Fagus sylvatica and Pinus sylvestris forests along a productivity and climate gradient through Europe. J. Ecol. 2018, 106, 746-760. [CrossRef]

85. Genet, A.; Auty, D.; Achim, A.; Bernier, M.; Pothier, D.; Cogliastro, A. Consequences of faster growth for wood density in northern red oak (Quercus rubra Liebl.). Forestry 2012, 86, 99-110. [CrossRef]

86. Grammel, R. Zusammenhänge zwischen Wachstumsbedingungen und holztechnologischen Eigenschaften der Fichte. For. Cent. 1990, 109, 119-129. [CrossRef]

87. Brazier, J.D.; Mobbs, I.D. The influence of planting distance on structural wood yields of unthinned Sitka spruce. Forestry 1993, 66, 333-352. [CrossRef]

88. Larocque, G.R.; Marshall, P. Wood relative density development in red pine (Pinus resinosa Ait.) stands as affected by different initial spacings. For. Sci. 1995, 41, 709-728.

89. Zhang, S.Y.; Chauret, G.; Swift, D.E.; Duchesne, I. Effects of precommercial thinning on tree growth and lumber quality in a jack pine stand in New Brunswick, Canada. Can. J. For. 2006, 36, 945-952. [CrossRef]

90. Moore, J.R.; Cown, D.J.; McKinley, R.B.; Sabatia, C.O. Effects of stand density and seedlot on three wood properties of young radiata pine grown at a dry-land site in New Zealand. N. Z. J. For. Sci. 2015, 45, 209. [CrossRef]

91. Tognetti, R.; Michelozzi, M.; Borghetti, M. The response of European beech (Fagus sylvatica L.) seedlings from two Italian populations to drought and recovery. Trees 1995, 9, 348-354. [CrossRef]

92. Bolte, A.; Czajkowski, T.; Cocozza, C.; Tognetti, R.; de Miguel, M.; Pšidová, E.; Ditmarová, L.; Dinca, L.; Delzon, S.; Cochard, H.; et al. Desiccation and mortality dynamics in seedlings of different European beech (Fagus sylvatica L.) populations under extreme drought conditions. Front. Plant Sci. 2016, 7, 751. [CrossRef] [PubMed]

93. Cocozza, C.; de Miguel, M.; Pšidová, E.; Ditmarová, L.; Marino, S.; Maiuro, L.; Alvino, A.; Czajkowski, T.; Bolte, A.; Tognetti, R. Variation in ecophysiological traits and drought tolerance of beech (Fagus sylvatica L.) seedlings from different populations. Front. Plant Sci. 2016, 7, 886. [CrossRef] [PubMed] 